\title{
Technical Analysis on Double Reheat for Ultra-Supercritical Units
}

\author{
Hai-ming Niu ${ }^{1,2} a^{*}$, Wei Zhang ${ }^{3, b}$ \\ ${ }^{1}$ Beijing Guodian zhishen control technology Co. Ltd \\ ${ }^{2}$ Beijing Engineering Research Center of Power Station Automation \\ ${ }^{3}$ East China Electric Power Design Institute Co. Ltd of China Power Engineering Consulting Group \\ a*nhm80@sohu.com, bhangw2699@ecepdi.com
}

Keywords: Double reheat, Ultra-supercritical units, Steam temperature control.

Abstract. Combined with the current requirements and development situation of ultra-supercritical units, analyze the impact of secondary reheat technology to ultra-supercritical units to improve efficiency and environmental benefits. Steam temperature control is a key to double reheat system, in addition to improving the material resistance unit, well-designed control system is essential. Common control strategies have reheat steam temperature control regenerative heating system, flue gas baffle and surface heat exchanger regulation, attemperating water and flue gas recirculation, flue gas bypass baffle and flue gas recirculation.

\section{Preface}

Thermal power plant energy consumption and pollutant emissions have a great influence on the environment, so that its energy saving and environmental protection have becoming the worldwide focus. By the end of 2012, China's installed capacity had reached 1.14491 billion kilowatts, of which 819.17 million kilowatts came from thermal power, $71.5 \%$ of the total installed capacity. It is foreseeable that for a long time in the future, the coal-based energy structure will not change. Therefore, the development of more efficient and cleaner ultra-supercritical thermal power units, further improvement in unit thermal efficiency, reducing in primary energy consumption and greenhouse gas emissions are necessary requirements to alleviate the current pressure .

To improve the efficiency of the unit, the world's major economies have launched the development of advanced ultra-supercritical power generation technology, and continuously improve the pressure and temperature of the first steam. Compared to the $25 \mathrm{Mpa} / 600^{\circ} \mathrm{C}$ units, the $35 \mathrm{Mpa} / 700^{\circ} \mathrm{C}$ ultra-supercritical units can increase the unit efficiency by about 8.2 percent, and lower about 6.5 percent emissions, which economic and environmental advantages are obvious [1]. Limited by metallic material, the steam temperature of current ultra-supercritical units can just reach 600 to $625^{\circ} \mathrm{C}$, and cannot meet the requirements of the development of advanced supercritical units. Though increasing the initial pressure can improve the efficiency of the units, with the increasing of the steam initial pressure, the steam wetness in turbine final stage will also increase. The use of single reheat steam turbine will lead to excessive humidity of exhaust steam in winter [2]. Double reheat steam turbine technology can improve the dryness of exhaust steam and eliminate or reduce the corrosion in the final stage blades.

\section{Development Trend of Ultra-Supercritical Units with Double Reheat}

Using double reheat can further improve the thermal efficiency of the units, and to meet the requirements of eventual exhaust steam humidity of the low pressure cylinder. From the beginning of the 1950s, the United States, West Germany, Japan and other countries have built double reheat turbines. No. Philo6 unit $\left(125 \mathrm{MW}, 31 \mathrm{MPa} / 621 / 565 / 538^{\circ} \mathrm{C}\right)$, built in 1957 ,United States, is the world's first ultra-supercritical units [3]. Statistics show that the United States puts a total of 25 double reheat units into operation by now. Japan began to put double reheat units into operation in the 1970s, typically the Kawagoe Plant with $700 \mathrm{MW}$ gas double reheat unit, $31 \mathrm{MPa} / 566 / 566 / 566{ }^{\circ} \mathrm{C}$. West Germany put $475 \mathrm{MW}$ double reheat coal-fired units into operation in $1979,25.5 \mathrm{MPa} / 530 / 540 / 530{ }^{\circ} \mathrm{C}$. 
In 1998, Denmark Nordjylland NO.3's 410MW ultra-supercritical coal-fired units, 29MPa / $582 / 580 / 580{ }^{\circ} \mathrm{C}$, with double reheat technology, makes it become the world's most efficient coal-fired power plants.

With the increasing tensions in the world's energy and breakthrough in material technologies, further improvement in the parameters of ultra-supercritical units is an inevitable trend. When the temperature reaches $650 \sim 720{ }^{\circ} \mathrm{C}$, the pressure exceeds $30 \mathrm{MPa}$, using double reheat will further enhance the efficiency of power plants, which can obtain excellent economy comparable to IGCC and PFBC power generation technology. United States, Japan, European Union, Russia and so have formulated relevant advanced ultra-supercritical technology A-USC (Advanced ultra-supercritical) development program [4]. According to "ADVANCED (" $700{ }^{\circ} \mathrm{C}$ ") PC POWER PLANT" program, raised by European turbine manufacturing, ABB, SIEMENS and GEC ALSTOM in main, parameters of ultra-supercritical units reach the level of $40 \mathrm{MPa} / 700{ }^{\circ} \mathrm{C} / 720{ }^{\circ} \mathrm{C}$. There are about 40 units from European countries participate in the work of this project, which has 26 equipment manufacturers (including manufacturers in turbines, boilers, main auxiliaries and materials, etc.), and others are relative research institutes, universities, power companies and other departments. Key topics covered: Ni-based alloy materials research, design and economic analysis for the two double reheat units (400MW and $1000 \mathrm{MW}), 700 \mathrm{MPa} / 720^{\circ} \mathrm{C} / 720^{\circ} \mathrm{C}$. America's first generation A-USC plants tended to using single reheat, then considered double reheat after technical and economic assessment; Japan proposed the development of $700{ }^{\circ} \mathrm{C}$ grade a-USC unit in " cool Earth Innovative Energy Plan" (Cool Earth-Innovative Energy Technology Program), enacted in 2008[5].

Since the 1990s, China began to introduce 600MW coal-fired supercritical units from abroad. In 2002, he first domestic 600MW supercritical coal-fired units put into operation in Qinbei Power Plant of Huaneng, and its technology has been rapid promoted in recent decade. However, compared with Europe, Japan, China still have certain gap in technical reserves and application of ultra-supercritical units. How to use our coal-fired units' dominant advantages to develop coal-fired ultra-supercritical units, to further improve the efficiency of the units is still a crucial problem machinery manufacturing industry and major power companies need to resolve. It's certainly a good solution to develop double reheat units to further improve the parameters of thermal power. Domestic construction of double reheat units are: Guodian Taizhou 2x1000MW double reheat units, Huaneng Laiwu 2x1000MW double reheat units and Huaneng Anyuan 2x660MW double reheat units.

\section{Efficiency Analysis of Ultra-Supercritical Double Reheat Units}

Improving steam parameters (steam's initial pressure and temperature), using reheat system, increasing reheat times, are effective ways to improve units' efficiency. In the ultra-supercritical range, the main steam's pressure being raised every $1 \mathrm{MPa}$, the unit heat rate can be decreased $0.13 \%$ to $0.15 \%$; the main steam's temperature being increased every $10{ }^{\circ} \mathrm{C}$, the units' thermal efficiency can be increased by $0.25 \%$ to $0.3 \%$; reheat steam's temperature being increased every $10{ }^{\circ} \mathrm{C}$, the unit thermal efficiency can be increased about $0.3 \%$ [6]. When the temperature reaches $650 \sim 720{ }^{\circ} \mathrm{C}$, and pressure over $35 \mathrm{Mpa}$,using the double reheat can acquire an equivalent economy with IGCC (Integrated Gasification Combined Cycle) power generation technology [7].

Figure 1 shows when the steam temperature remains constant how the steam pressure effects on the thermal efficiency of the units. When the pressure is lower than 30MP,the units' thermal efficiency rises rapidly with the increasing pressure, and rises to a lesser extent when it goes higher than 30MP. 


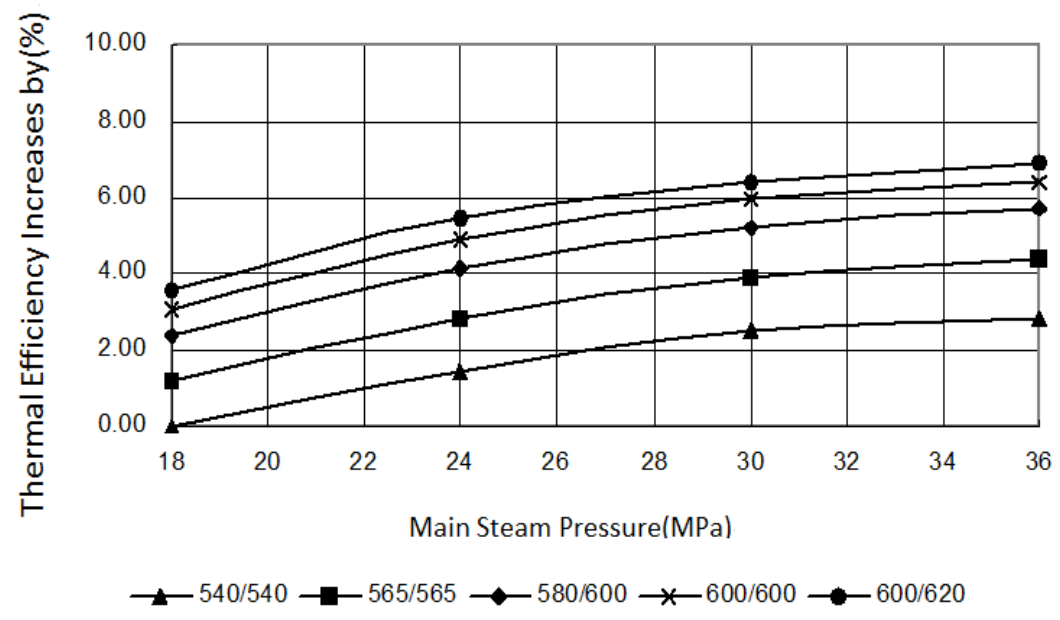

Fig 1.Effect of Increasing Initial Pressure on Thermal Efficiency of The Unit in Various Steam Parameters

Fig 2 and 3 denote respectively when the single reheat and double reheat steam temperature remains constant, how the change of steam pressure effects on the thermal efficiency of the unit.

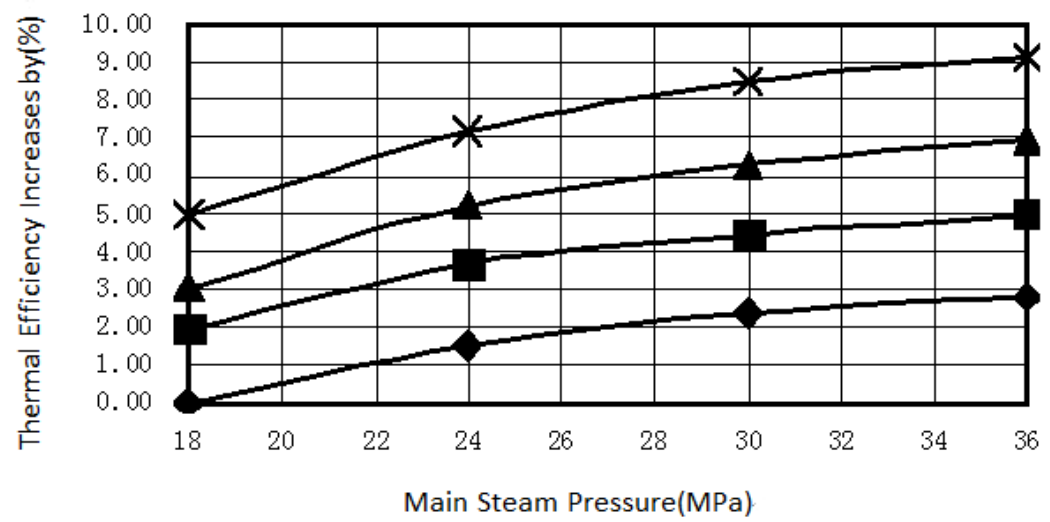

$\longrightarrow 540 / 540 \longrightarrow 560 / 540 / 540 \longrightarrow 560 / 600 / 600$

Fig 2.Relative Increasing Value of Single Reheat Units' Thermal Efficiency

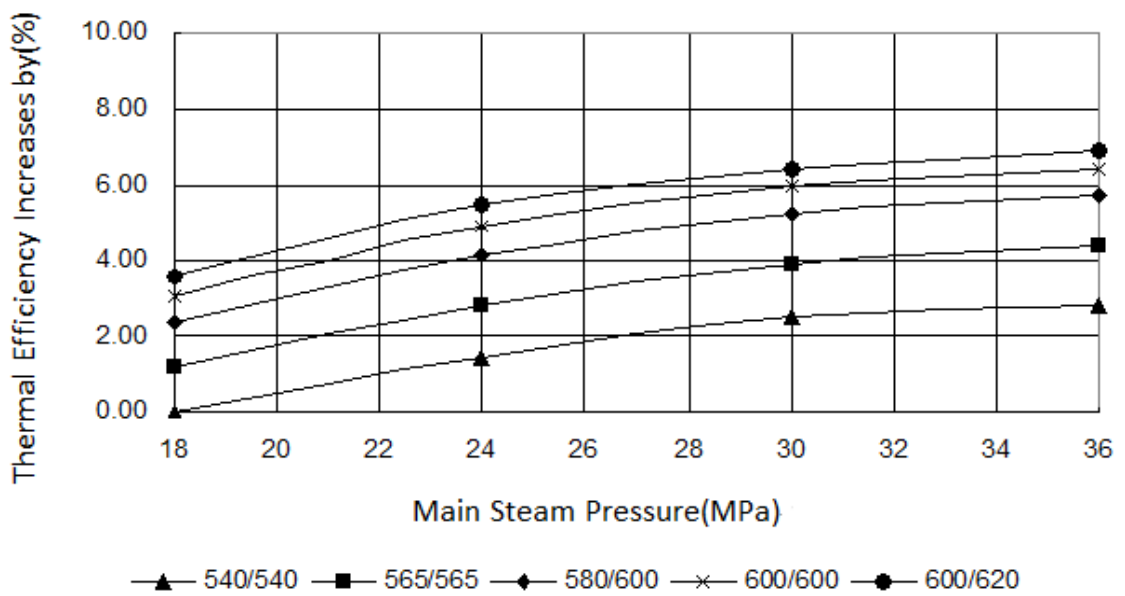

Fig 3.Relative Increasing Value of Double Reheat Units’ Thermal Efficiency 
With the improving of pressure, the hydrograph move to the left in the Mollier diagram, which makes turbine final stage humidity increase, and the water erosion of final stage rotor blade tending to be serious. Low-pressure cylinder's exhaust steam humidity should not exceed $12 \%$ of maximum. If the steam parameters are $28.0 \mathrm{MPa}, 580{ }^{\circ} \mathrm{C} / 600{ }^{\circ} \mathrm{C}$, and steam turbine back pressure is $4.9 \mathrm{kPa}$, the exhaust humidity will reach $10.7 \%$. Under the conditions of main steam temperature / reheat steam temperature are $600{ }^{\circ} \mathrm{C} / 600{ }^{\circ} \mathrm{C}$, and main steam pressure $>30 \mathrm{MPa}$, if not using the double reheat, turbine final stage humidity has exceeded the design specifications.

Currently, some of the operating double reheat units around the world are shown in Table 1. As can be seen from Table 1, after the 1980's, the best coal-fired unit is Danish Nordjylland NO.3, which efficiency is $47 \%$.

Table 1. Some of The Operating Double Reheat Units Around The World

\begin{tabular}{|l|c|l|l|l|c|}
\hline \multicolumn{1}{|c|}{ Power station } & Cap.(MW) & $\begin{array}{c}\text { Steam } \\
\text { parameters(MPa/ } \\
\text { C/ }{ }^{\circ} \text { C) }\end{array}$ & \multicolumn{1}{|c|}{ Fuel } & Efficiency & $\begin{array}{c}\text { Year of } \\
\text { Comm. }\end{array}$ \\
\hline Philo NO.6 in ohio USA. & 125 & $31 / 621 / 565 / 538$ & coal & & 1957 \\
\hline Eddystone NO.1 in USA & 325 & $34.5 / 649 / 565 / 565$ & coal & & 1959 \\
\hline Hudson NO.2 in USA & 650 & $26.7 / 541 / 555 / 570$ & $\begin{array}{l}\text { coal,na } \\
\text { tgas }\end{array}$ & & 1968 \\
\hline Big sadie NO.2 in USA & 835 & $26 / 543 / 552 / 566$ & coal & & 1969 \\
\hline $\begin{array}{l}\text { West Germany mannheim } \\
\text { thermal power plant NO.7 } \\
\text { in USA }\end{array}$ & 475 & $25.5 / 530 / 540 / 530$ & coal & $42 \%$ & 1979 \\
\hline $\begin{array}{l}\text { Himeji second power plant } \\
\text { N0.6 in Japan }\end{array}$ & 600 & $25.4 / 541 / 554 / 568$ & $\begin{array}{l}\text { oil,nat } \\
\text { gas }\end{array}$ & & 1973 \\
\hline Kawagoe N0.1 in Japan & 700 & $31 / 566 / 566 / 566$ & nat gas & $41.9 \%$ & 1989 \\
\hline Kawagoe N0.2 in Japan & 700 & $31 / 566 / 566 / 566$ & nat gas & $41.9 \%$ & 1990 \\
\hline $\begin{array}{l}\text { Skærbæk NO.3 in } \\
\text { Denmenk }\end{array}$ & 400 & $29 / 580 / 580 / 580$ & nat gas & $49 \%$ & 1997 \\
\hline $\begin{array}{l}\text { Nordjylland NO.3 in } \\
\text { Denmenk }\end{array}$ & 400 & $29 / 580 / 580 / 580$ & coal & $47.0 \%$ & 1998 \\
\hline
\end{tabular}

Average power supply coal consumption for $1000 \mathrm{MW}$ ultra-supercritical unit is $292 \mathrm{~g} /(\mathrm{KW} \cdot \mathrm{h})$ approximately, the best of them is $279 \mathrm{~g} /(\mathrm{KW} \cdot \mathrm{h})$, and expected power supply coal consumption for ultra-supercritical double reheat unit can under $251 \mathrm{~g} /(\mathrm{KW} \cdot \mathrm{h})$, According to China's current total installed capacity of thermal power calculation 620 million $\mathrm{kW}$, coal can be extremely significant savings. And due to the significant reduction in coal for power generation, so that contaminants into the atmosphere will be reduced accordingly, and with the improvement of the thermal efficiency of thermal power units, $\mathrm{CO} 2$ emissions for per unit power generation will be significantly reduced. Double reheat units' environmental benefits will be significant.

\section{Steam Temperature Control Strategy of Ultra-supercritical Double Reheat units}

Regenerative heating system

Nordjylland NO.3 unit in Denmark is currently the most efficient thermal power unit, in which there are 2 mixed heaters. The steam-water system and the steam parameters is shown in figure 4 . 


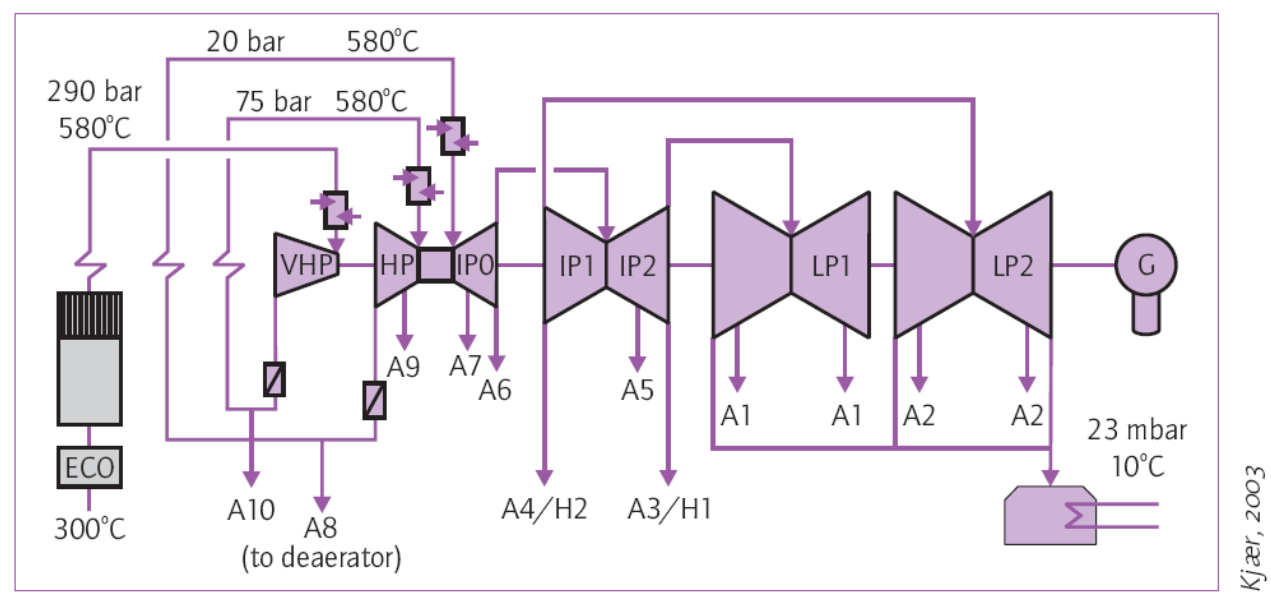

Fig.4 Steam-water system at Nordjylland NO.3 Unit in Denmark

\section{Reheat steam temperture control}

Adopting double reheat design will make the unit more complicated. For example, double reheater will make boiler structure more complex, such as the ultra-supercritical pressure cylinder, the cold steam pipe and hot steam pipe in reheat steam system, the ultra-supercritical pressure main stop valves and control valves, the increasing the length of shaft. Higher control requirements in the unit running are needed and many technical problems need to be solved. Due to all of these, steam temperature control is one of the key technologies, which may have to control the main steam temperature and two levels of reheat steam temperature, considering the interaction between these three temperature, so steam temperature in double reheat unit is more difficult to control than single reheat unit to control.

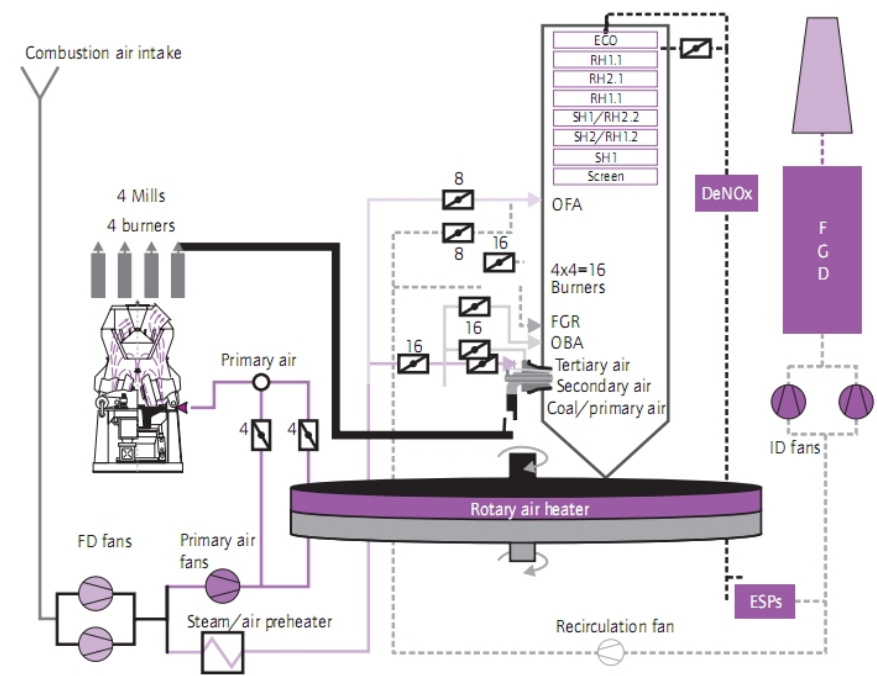

Fig.5 Air and Gas System at Nordjylland NO.3 Unit in Denmark

Generally, the steam temperature control strategy is as follows:

(1) Gas damper and surface heat exchanger adjusted

As for Himeji second power plant no. 6 Boiler in Japan, first reheater arrangement in a side of the tail flue in front of the boiler, and adjust first export reheat steam temperature by the flue gas damper in flue outlet. Second reheater arrangement in other side of the tail flue after the boiler, vertical portion disposed at a higher level at the flue gas temperature flue, surface heat exchanger between those adjust steam temperature in secondary reheater. Cryogenic fluid come from main feed water, flowed to the economizer after the heat transfer.

(2) Attemperating water and flue gas recirculation 
Nordjylland NO.3 in Denmark is a ultra-supercritical double reheat unit using seawater cooling, which control first reheat temperature by trace water spray, and using flue gas recirculation adjust Secondary reheating temperature, As shown in figure 7.Flue gas from the economizer (ECO), after stock and electrostatic precipitators (ESPs) dusted into the rotary air preheater, which temperature dropped to $115^{\circ} \mathrm{C}$ and back into the boiler, and control secondary reheating temperature by adjusting flue gas circulation.

(3)Flue gas bypass baffle and flue gas recirculation

Japan Kawagoe No.2 furnace adjusts first and secondary reheater temperature by flue gas bypass baffle and flue gas recirculation combination. Unit of boiler heating surface at the back of the flue is equipped with first-class horizontal superheater respectively, two primary reheater, secondary reheater of four channels, and in each channel exit flue gas distribution damper installation, which adjusted by altering the flue flow ratio and flue gas recirculation, which improved the steam temperature control performance and efficiency of the unit compared to water temperature reduction.

\section{Conclusion}

Ultra-supercritical units improved initial steam parameters, which can effectively make unit efficiency better and achieve energy saving purposes. In order to ensure The last stage blade in cylinder exhaust steam moisture to meet the requirements, while enhancing the initial pressure and must increase the initial temperature, and raising the temperature of the need have to develop more resistant to high temperature of metal materials. Before $700{ }^{\circ} \mathrm{C}$ nickel-based materials can be large-scale application, the development of secondary reheat unit is a good choice to improve the efficiency of ultra-supercritical units. There are two reheaters in double reheat unit, boiler heating surface is arranged more complicated, and influence factors of steam temperature are also more than single reheat unit, the unit run at high parameters for a long time is more stringent in temperature steam requirements, reasonable choice of steam temperature control scheme and research of control strategy is the key to ultra-supercritical double reheat unit stable operation.

\section{Acknowledgement}

This paper is supported by National Key Technology Support Program(2012BAA12B06).

\section{References}

[1] Yun-ze Li, Xian-yong Yan, Jun-jie Yan and others, Secondary reheat supercritical thermal system liner analysis using three coefficients [J] Chinese CSEE, 2002,22 (6): 132-136.

[2] OECD, Case Studies of Recently Constructed Coal- and Gas-Fired Power Plants, Fossil Fuel-fires power generation[M], 2007.

[4] P.S. Weitzel. Steam Generator for Advanced Ultra-Supercritical Power Plants 700 to $760^{\circ} \mathrm{C}[\mathrm{C}]$. ASME 2011 Power Conference.

[5] Masafumi Fukuda, Advanced USC Technology Development in Japan[J]. Advances in Materials Technology for Fossil Power Plants , p 325-341, 2011.

[6] George J. Silvestri, Jr. Eddystone Station, 325 MW Generating Unit 1 a Brief History, 2003.

[7] JørgenBugge, SvenKjær, RudolphBlum. High-efficiency coal-fired power plants development and perspectives[J], Energy31(2006):1437-1445.

[8] Klaus M. Retzlaff, W. Anthony Ruegger, Steam Turbines for Ultra-supercritical Power Plants, GE Power Generation GER-3945A. 